\title{
Chlamydia psittaci in ocular adnexa MALT lymphoma: a possible role in lymphomagenesis and a different geographical distribution
}

\author{
Francesca Collina', Anna De Chiara ${ }^{1}$, Amalia De Renzo ${ }^{2}$, Gaetano De Rosa ${ }^{3}$, Gerardo Botti ${ }^{1}$ and Renato Franco ${ }^{1,4^{*}}$
}

\begin{abstract}
Ocular adnexa MALT-lymphomas represent approximatively 5-15\% of all extranodal lymphomas. Almost $75 \%$ of OAMLs are localized in orbital fat, while $25 \%$ of cases involves conjunctive. MALT-Iymphomas often recognize specific environmental factors responsible of lymphoma development and progression. In particular as Helicobacter pylori in gastric MALT lymphomas, other bacterial infections have been recognized related to MALT lymphomas in specific site. Recently Chlamydia psittaci has been identified in Ocular Adnexa MALT lymphomas, with variable frequence dependently from geographic areas. Thus bacterial infection is responsible of clonal selection on induced MALT with subsequent lymphoma development. Moreover Chlamydia psittaci could promote chromosomal aberration either through genetic instability as a consequence of induced proliferation and probably through DNA oxidative damage. The most common translocation described in MALT lymphomas affects NF-kB pathway with a substantial antiapoptotic effect. Several therapeutic approaches are now available, but the use of antibiotic-therapy in specific cases, although with conflicting results, could improve the treatment of ocular adnexa MALT Iymphomas. In this review we analyse the most relevant features of Ocular adnexa MALT lymphomas, underlining specific biological characteristics mainly related to the potential role of Chlamydia psittaci in lymphomagenesis.
\end{abstract}

Keywords: Chlamydia psittaci, Ocular Adnexa, MALT lymphoma, t(14;18), bcl10

\section{Background}

Non-Hodgkin's lymphomas represent the most common ocular adnexa neoplasm [1]. Approximately accounting 5$15 \%$ of all extranodal lymphomas localize at ocular adnexa, including the conjunctiva, the lachrymal gland, the orbital fat, the eyelid and the lachrymal sac [2]. In Western countries Marginal zone B-cell lymphoma of mucosa-associated lymphoid tissue (MALT)-type accounts $50-78 \%$ of all ocular lymphomas, while in Japan and Korea the relative frequence is much higher [3]. It has been recorded that Ocular Adnexal MALT Lymphoma (OAML) increases by more than $6 \%$ for year. These data are only partially explained by the development of recent new lymphoma classification and improvement of diagnostic approaches [4].

\footnotetext{
* Correspondence: renfr@yahoo.com

'Pathology Unit, National Cancer Institute "Giovanni Pascale", Naples, Italy Full list of author information is available at the end of the article
}

MALT-lymphomas represent a wide range of extranodal lymphomas that often recognize environmental factors driving to specific genes deregulation. Interestingly, environmental factors are specifically related to sites of acquired MALT development and furthermore the deregulated genes, even if involved in the NF-kB pathway, share different distribution in extranodal sites [5,6]. Among environmental factors, some bacterial infections have been found associated to MALT lymphomas of specific anatomic districts, such as $\mathrm{H}$. pylori in gastric MALT lymphoma, C. Jejuni in intestinal MALT lymphoma and Borrelia Burgdoferi in cutaneous B cell lymphoma [6-10]. Recently Chlamydia psittaci (Cp) has been identified in OAML [11-25]. Chromosomal aberrations involving mainly MALT1 and bcl10 genes with consequent deregulation of their gene expression are commonly observed in MALT lymphomas, but with different distribution dependently from specific anatomic regions, being $t(11 ; 18)$ more frequent in gastric MALT lymphomas and t $(14 ; 18)$ in extragastric MALT
C Biomed Central 
lymphoma [26-29]. Moreover environmental and biological features show a relevant variability also related to geographic area. In fact $\mathrm{Cp}$ frequence in OAML has been described with difference frequence all over the world (Table 1) [11-25].

Thus this variability reflects different therapeutic strategies, that apart conventional chemotherapy and radiotherapy, are also based on specific targets or biomarkers useful to predict therapeutic response [30].

\section{Clinical features}

Almost 75\% of OAMLs are localized in orbital fat, while $25 \%$ of cases involves conjunctive [19,31-34]. Bilateral involvement has been described in 15\% of OAMLs [19,31-34]. It arises after fourth decade, more frequently in female [19,31-34]. $38 \%$ of patients show at least one extraorbital site with lymphoma localization at accurate staging of OAML [35] In some cases autoimmune disorders are concomitant [36].

Clinical presentation depends upon involved orbital region, being exophthalmos (27\% of cases), palpable mass (19\%), eyelid ptosis (6\%), diplopia (2\%), eyelid nodule, orbital edema, epiphora and a variable degree of impaired ocular motility the most frequent signs and symptoms for orbital fat lymphomas, while 'salmon red patch' is the most common feature of conjunctival lymphomas [18,30-33]. Rarely impairment of extraocular muscle and infiltration of eyes have been recorded [37]. Diagnosis requires integrated study through computed tomography, magnetic resonance and imaging (MRI) and A- and Bscan orbital ultrasonography.

OAML patients exhibit a favorable outcome, when adequately treated $[19,38]$. Nodal involvement $(<5 \%$ of

Table 1 Worldwide distribution of $\mathrm{Cp}$ infection

\begin{tabular}{lll}
\hline Geographical area & $\% \mathrm{Cp}+$ & Reference \\
\hline North Italy & $87 \%$ & {$[11]$} \\
\hline Korea & $79 \%$ & {$[13]$} \\
\hline Austria & $54 \%$ & {$[14]$} \\
\hline Germany & $47 \%$ & {$[15]$} \\
\hline East coast USA & $35 \%$ & {$[15]$} \\
\hline Netherlands & $29 \%-0 \%$ & {$[15] \&[24]$} \\
\hline Central Italy & $13 \%-16 \%$ & {$[15] \&[17]$} \\
\hline UK & $12 \%$ & {$[15]$} \\
\hline Southern China & $11 \%$ & {$[15]$} \\
\hline Cuba & $10 \%$ & {$[16]$} \\
\hline Africa & $0 \%$ & {$[17]$} \\
\hline Rochester (New York) & $0 \%$ & {$[18]$} \\
\hline Southern Florida & $0 \%$ & {$[19] \&[21]$} \\
\hline North China & $0 \%$ & {$[20]$} \\
\hline Japan & $0 \%$ & {$[22] \&[23]$} \\
\hline
\end{tabular}

cases), systemic symptoms (1\%), increased lactate dehydrogenase serum levels (1\%) and non-conjunctival sites are considered negative prognostic factors $[18,31,32]$. Moreover these parameters seem to be related to highgrade transformation, recorded in $1-3 \%$ of cases $[38,39]$. 5 -year relapse-free survival rate is $65 \%$. Systemic dissemination has been observed in $5-10 \%$ of cases and only $5 \%$ of OAML patients die of lymphoma, with a 5 -year overall survival of $>90 \%[33,34]$. Some cases of spontaneous tumor remission in OAML patients have been reported, mostly in Japanese patients with conjunctival MALT lymphoma [40].

\section{Histopathology}

OAML derives from acquired MALT in orbital region and from probably native MALT in conjunctive. MALT acquisition is consequent to chronic inflammation due to autoimmune disorders or infection [41]. Microscopically neoplastic cells are monocytoid, centrocytic-like or lymphoplasmocitoid (Figure 1). OAML are characterized by prevalence of one of mentioned cell types [30]. In the regional district containing epithelium such as conjunctive and lacrimal gland, lymphoepithelial lesions, i.e. lymphoma cells invasion of epithelial structures, could be observed. Follicular colonization with lymphoma cells invasion of germinal centers is sometimes present. Single or clustered large cells can be also observed. OAML is always associated to non-neoplastic cells and reactive secondary follicles.

Immunoprofile is similar to other MALT lymphoma, being neoplastic cells CD20+ (Figure 2a), CD79a+, CD3-, CD5-, CD10-, bcl-6-, IgM+, bcl-2+, CD43+/-, CD23-/+, CD21+/-, TCL1+, PAX5+, CD11c+/-, CD35+/-, and IgD-, cyclin D1-, MUM1- [5,30]. Differential diagnosis of OAML is generally with other small cells lymphomas, such as mantle cell lymphoma, follicular lymphoma and small lymphocytic lymphoma and with reactive lymphoproliferative disorders. Specific immunohistochemical profile of other low grade lymphomas could help in the correct diagnosis of OAML, while pseudolymphomatous proliferation often requires molecular deepening, taking into account that pathological entities previously classified as 'pseudolymphomas' or 'benign lymphoid hyperplasia' are actually considered very rare, since most of them contain clonal B cells [42].

\section{Pathogenesis: General mechanisms and infectious agents}

The MALT lymphomas arise in tissues with native or acquired MALT. When acquired, it derives from reactive lymphoid tissue developed to persistent antigenic stimulation, such as chronic inflammation or an autoimmune disorder. The nature of inflammatory processes in these patients is almost always unknown. As Helicobacter pylori 

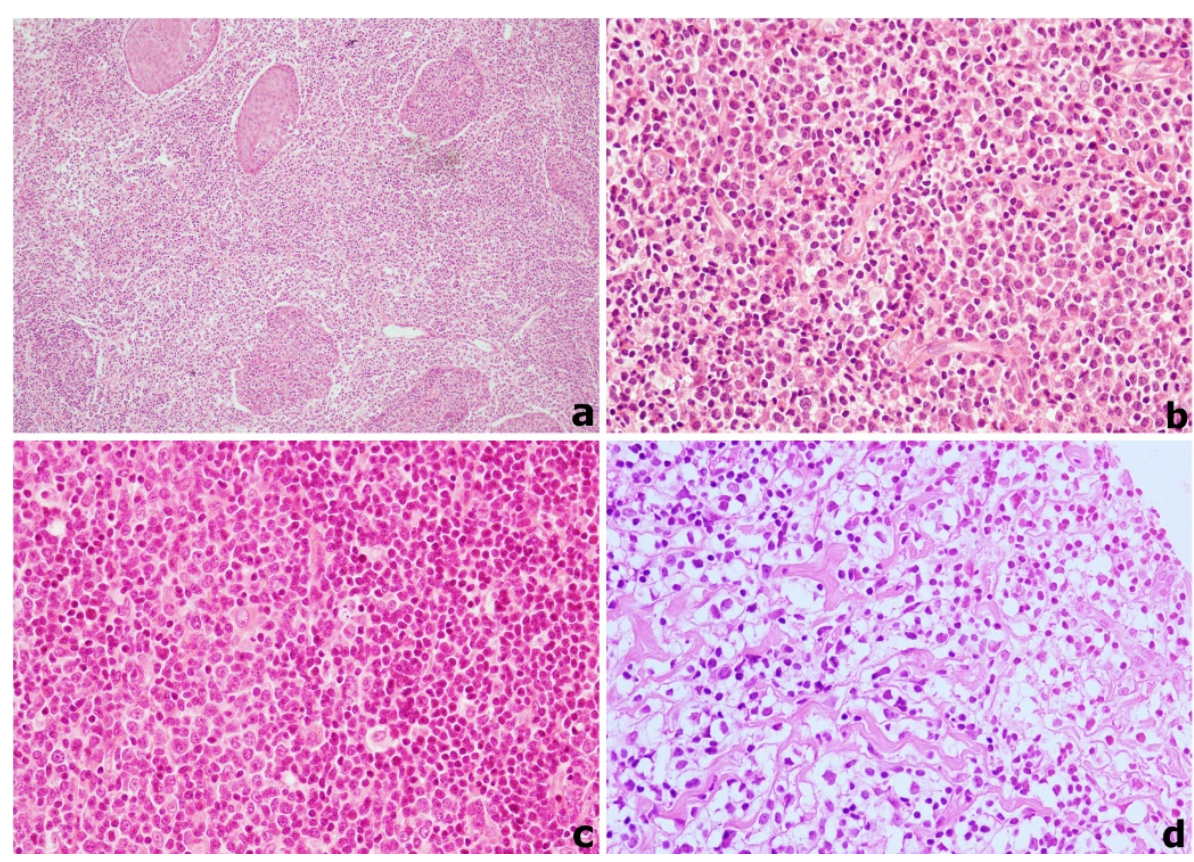

Figure 1 (a) OAML infiltration of the lacrimal gland, showing squamous metaplasia (H\&E) (10X); (b) prevalence of plasmocytoid cells in OAML (H\&E) (40X); (c) prevalence of centrocytic cells around a residual germinal center in OAML (H\&E) (40X); (d) prevalence of monocytoid cells in OAML (H\&E) (40X).

(Hp) plays a relevant role in development of gastric MALT lymphomas, other infectious agents have been investigated in other districts usually sites of MALT lymphomas. Thus for cutaneous B cell lymphomas Borrelia burgodoferi has been found associated in a significant subset, especially in specific geografic areas [10,43-45], while at small intestine Campylobacter jejuni seems to be responsible of MALT lymphoma development [9]. Finally for OAML a similar

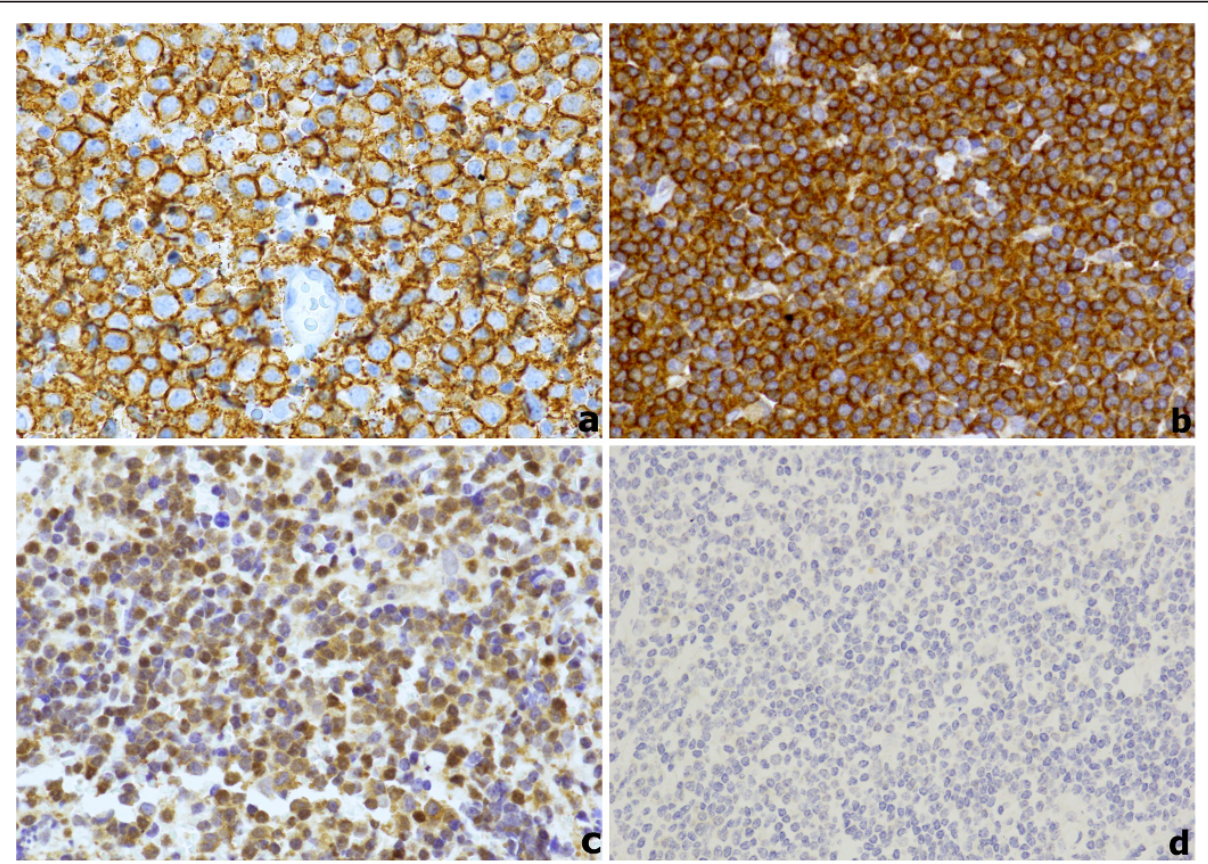

Figure 2 CD20 and Bcl10 immunohistochemical expression; (a) Diffuse CD20 staining (60x); (2) High cytoplasmic Bcl10 expression (40x); (3) High nuclear Bcl10 expression (40x); (d) Negativity for Bcl10 (40x). 
pathogenic role for Chlamydia psittaci has been proposed. In this context, a B-cell clonal expansion and proliferation could occur (Figure 3), as indicated by the presence of somatically hypermutated immunoglobulin genes with an ongoing mutations pattern. Chronic antigenic stimulation may induce genetic instability with subsequent chromosomal abnormalities, which, associated with the microenvironment, can make the process of clonal growth independent from antigenic stimulation. In addition tumor progression to a more aggressive histologic type of lymphoma (DLBCL) can then be induced by mutations of tumor suppressor genes such as p53 and p16 [46-49] (Figure 4).

The geographical difference in incidence of $\mathrm{Cp}$ infection suggests that other agents commonly associated with chronic eye diseases can play a key role in the initiation of neoplasia, as Chlamydia abortus [50], Chlamydia trachomatis, herpes simplex virus type 1 and 2 and adenovirus type 8 and 19 [29,51].

C. pneumonia infection has been hypothesized to be casually associated with different types of malignancies, including cutaneus T-cell lymphoma [52,53], and lung cancer [54], but also B cell lymphomas. Infact C. pneumonia DNA has been detected in a Chinese patient with bilateral orbital MALT lymphoma and then associated with Helicobacter pylori $(\mathrm{Hp})$ in a French patient
[53,55]. Hp infection has been also detected in one third of a series of Italian OAML patients and in a series of 15 Korean patients with conjunctiva MALT lymphoma $[56,57]$. However the association between Hp infection and OAML remains controversial [58]. In fact Sjo et al. failed to identify association between Hp infection and 13 analyzed cases of conjunctival MALT lymphoma through immunohistochemistry and nested polymerase chain reaction (PCR) techniques $[30,59,60]$. Finally there is increasing molecular and epidemiological evidence of the pathogenetic role of Hepatitis $C$ virus in hepatitis Cassociated OAML. Two Italian studies showed HCV seropositivity in $13-36 \%$ of patients OAML, which seemed to be associated with more aggressive disease than HCV-negative patients $[61,62]$.

\section{Chlamydia psittaci in OAML}

Chlamydia psittaci is an obligate intracellular bacterium causing pulmonary psittacosis in humans and Chlamydiosis in the avians, including pneumonitis, pericarditis, conjunctivitis, air sacculitis, peritonitis and hepatosplenomegaly [63]. The human psittacosis is generally caused by exposure to infected animals. Morphologically Chlamydophila can present in three different forms: elementary body (EB), reticulate body (RB) and intermediate body (IB). The EB is a small spherical body, of about

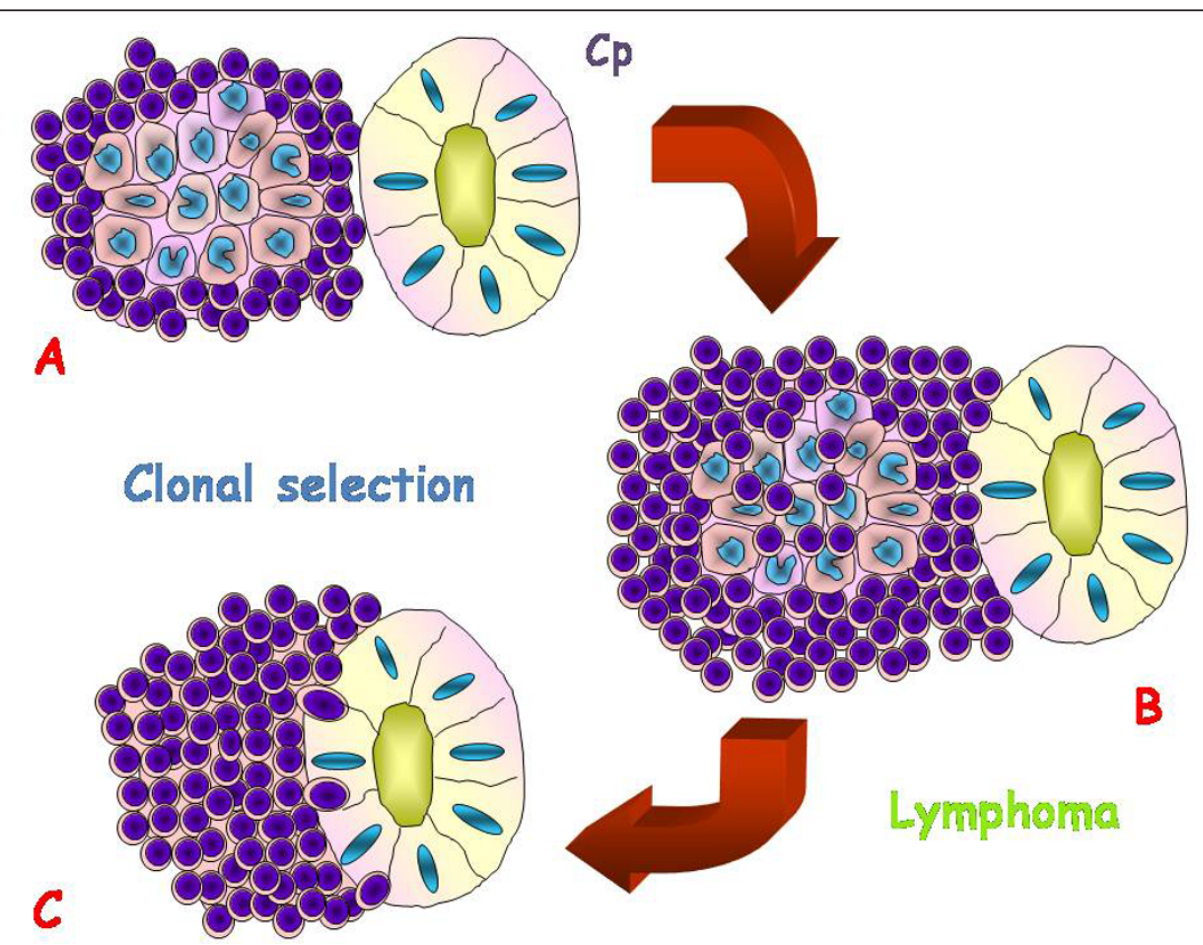

Figure 3 Schematic representation of lymphomagenesis potentially induced by Chlamydia psittaci (Cp) in acquired MALT with follicular germinal center (A) with consequent clonal selection, characterized by clonal expansion of marginal zone lymphoid cells invading (B) and then replacing germinal center (C) 


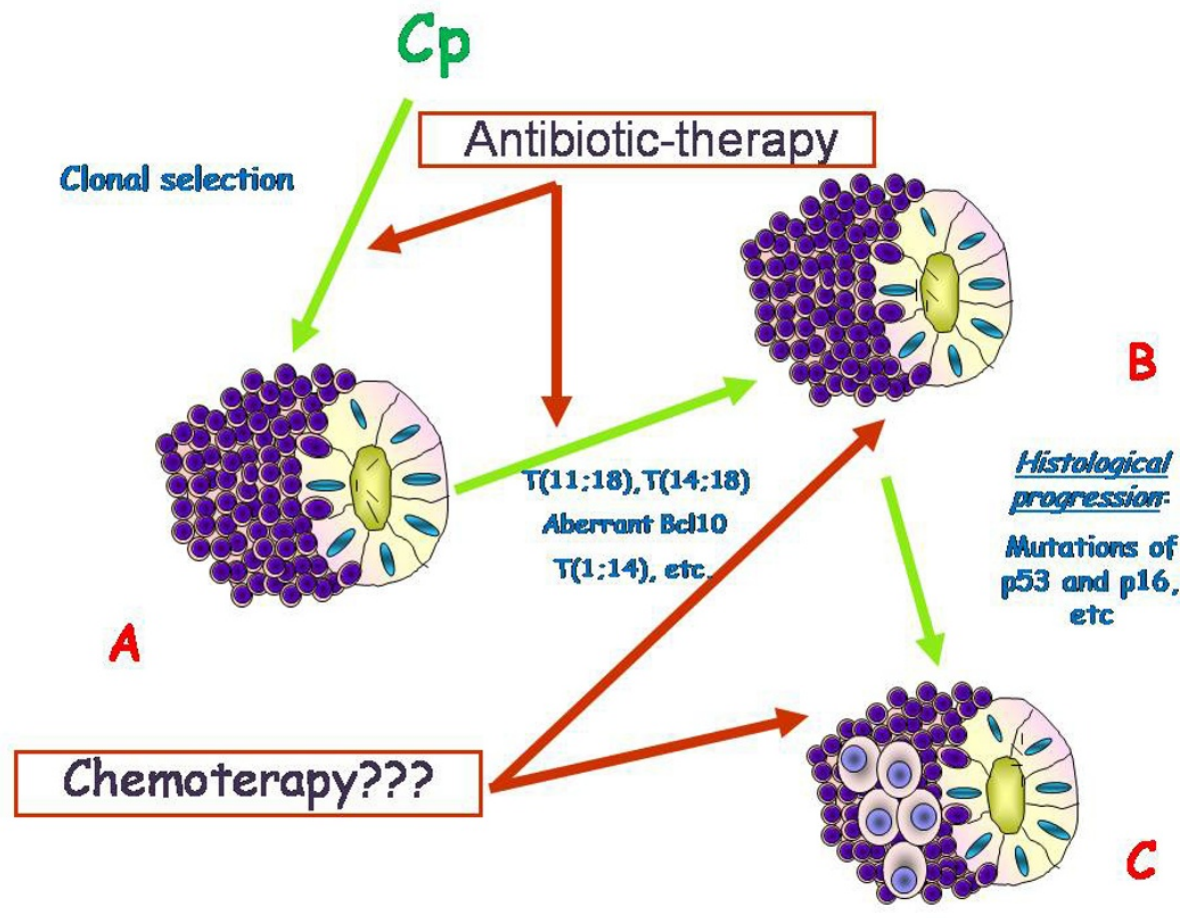

Figure 4 Schematic representation of OAML biological progression from Cp-clonal selection (A) to lymphoma with chromosomal aberration (B) and finally to histological progression to Diffuse Large B cell Lymphomas (C). Antibiotic therapy could be efficacy only in the phase of $\mathrm{CP}$ antigen dependent growth.

0.2-0.3 $\mathrm{mm}$ in diameter, characterized by highly electron-dense nucleoid, at the periphery and separated from an electron-dense cytoplasm. The EB is the infectious form, which attaches to the target cell and finally enters it. After entering the host cell, the EB takes the shape of RB (0.5-2.0 mm), which is the metabolically active intracellular form. In the transition from one form to another, an intermediate form IB, measuring about 0.3-1.0 mm, could be observed [63]. Using a combination of PCR and immunohistochemistry, Ferreri et al. detected Cp DNA in $87 \%$ of OAML cases in a Northern Italy series, establishing an association between infection of $\mathrm{Cp}$ and the OAML [11]. Later, the same group of authors provided further evidences that a complete or partial regression was achieved in some cases of ocular adnexal MALT lymphoma, including cases negative for $\mathrm{Cp}$, following anti-chlamidial antibiotic therapy $[11,12,20,64]$. Similar findings have been reported from Korean studies, since Cp-DNA was detected in $79 \%$ of patients [13]. Finally high prevalence of $\mathrm{Cp}$ has been observed in Austrian series [14].

A recent study on ocular adnexal MALT lymphoma cases from six geographic areas showed marked variation of the association between infection and OAML among the regions examined, being most frequent in Germany (47\%), followed by the USA (35\%), and the Netherlands
(29\%), but relatively low in central Italy (13\%), the UK (12\%) and southern China (11\%) [15]. Low prevalence (10\%) of Cp infection was also found in cases from Cuba [16]. Moreover studies from the South Florida and Rochester (New York) areas of the USA, Netherland, Japan, Africa and Northern China, France have reported absence of the association between $\mathrm{Cp}$ infection and OAML [17-25]. Another recent study comparing cases of Central Italy and African OAML underlines a low frequency of $\mathrm{Cp}$ infection in Italian series, accounting almost 16\% of cases, and absence of Cp infection in African cases [17]. All these findings suggest that there is a geographic variability for $\mathrm{Cp}$ association and OAML and that other etiological factors may be involved in the development of this lymphoma [17].

Recently the role of $\mathrm{Cp}$ has been proposed in the pathogenesis of other non gastrointestinal MALT, since Cp DNA has been recently evidenced as in all tested lung MALT lymphomas, in $30 \%$ of thyroid MALT lymphomas, $25 \%$ of skin MALT lymphomas and $13 \%$ of salivary gland MALT lymphomas. Moreover $\mathrm{Cp}$ has been revealed in $41 \%$ of the autoimmune disease Sjögren syndrome and Hashimoto thyroiditis, as potential precursor of specific subsets of MALT lymphomas. A potential, direct cancerogenic role of $\mathrm{Cp}$ has been suggested. In fact, these microorganisms, which establish persistent infections, are 
mitogenic in vitro [65], cause resistance to apoptosis in infected cells [66] and induce polyclonal cell proliferations in vivo $[67,68]$.

Heat-shock proteins produced by $\mathrm{Cp}$ may trigger immune responses, both humoral and cell-mediated, which can generate a cross-reactivity against human proteins and other self antigens [69]. This phenomenon may contribute to alter local tolerance, leading to chronic stimulation by antigens [70]. The role of $\mathrm{Cp}$ is not only restricted to lymphoid proliferation induction, but it seems to be responsible of chromosomal aberration, probably due to its mitogenic activity or indirectly induced oxidative damage $[26,65]$. As in gastric MALT lymphomas $t$ $(11 ; 18)$ were significantly associated with CagA-positive strains of $\mathrm{H}$ pylori, probably due to oxidative damage on DNA induced by CagA-positive strains of $\mathrm{H}$ pylori, in OAML could be suggested the same phenomenon [26]. In fact some infectious agents, as $H$ pylori strains harboring the CagA island, cause a potent neutrophil activation through interleukin-8 activity [71]. Finally neutrophils activation is responsible of oxygen-reactive release, causing DNA damage, as double-strand breaks [72]. Whatever the mechanism responsible for chromosomal aberration occurs, the clonal expansion would virtually become independent of antigenic stimulation. Thus frequently infectious agents are not detected in MALT lymphomas with chromosomal aberrations [20]. In fact in gastric MALT lymphomas the presence of $\mathrm{t}(11 ; 18)(\mathrm{q} 21 ; \mathrm{q} 21)$ correlates with resistance to antibiotic therapy, since neoplastic proliferation has become independent from infectious disease [73-75]. In addition, relative unfrequent positivity of $\mathrm{Cp}$ DNA in diffuse large B-cell lymphomas respect to OAML, is probably consistent with the possibility that the $\mathrm{Cp}$ can lead marginal zone lymphomas to progress to a more aggressive histotype (i.e., diffuse large B-cell lymphomas), which is no longer responsive to (and dependent on) the antigenic stimulation provided by the microorganism [11].

\section{Genetic aberration}

Recurrent genetic abnormalities have been described in extranodal MALT lymphomas. Trisomy of chromosome 3 and chromosome 18 are observed in up to $68 \%$ and $57 \%$ of patients, respectively $[27,57,76-78]$. Gain of chromosome 3 has been shown to be more common in orbital, than in lacrimal gland and conjunctival OAML [76]. Trisomy of chromosome 18, instead, is more frequent in the conjunctival OAML and predominantly affects young women [78]. Comparative genomic hybridization (CGH) carried out in 10 OAML cases showed recurrent chromosomal gains at $6 \mathrm{p} 21$ and $9 \mathrm{q} 33$-qter, in addition to trisomy 3,12 and 18 [79].

One of the most frequent translocation in MALT lymphoma is $\mathrm{t}(11 ; 18)$ (q21;q21) (Figure 5a). It is demonstrated in $10-50 \%$ of gastric MALT lymphomas, whereas this translocation rarely occurs in non-gastric MALT lymphomas, with the exception of pulmonary MALT lymphomas [27]. Translocation fuses the N-terminal region of the API2 (apoptosis inhibitor 2) gene (located at chromosome 11) to the C-terminal region of the MALT1 gene (located at chromosome 18), creating the API2-MALT1 chimeric fusion protein [80-83], which gains the ability to activate the NF-kB pathway $[84,85]$. However the most common translocation in ocular adnexal MALT lymphomas is the $t$ $(14 ; 18)$ (q32;q21) (Figure 5b), which seems to be one of the main pathogenic mechanisms leading to reduced apoptotic activity, resulting in uncontrolled expression of MALT1 by bringing the MALT1 gene under the control of the $I G H$ enhancer, a mechanism similar to that used by $\mathrm{t}(1 ; 14)$. Also $\mathrm{t}(1 ; 14)$ (p22; $\mathrm{q} 32$ ) (Figure 5c) does not form a fusion gene, but rather brings the entire coding region of the $B C L 10$ gene on chromosome 1 under the control of the enhancer region of $I G H$ gene on chromosome 14, leading to uncontrolled expression of the BCL10 gene [86]. Bcl10 is an intracellular protein that is essential for both the development and function of mature $\mathrm{B}$ and $\mathrm{T}$ cells. Recent studies show that BCL10 specifically links antigen receptor signaling in $\mathrm{B}$ and $\mathrm{T}$ cells to NF-kB activation $[87,88]$. In MALT lymphomas arising at gastrointestinal locations, it is claimed that MALT1, with or without bcl10 cooperation, activates the phosphorylation cascade, leading to IkB- $\alpha$ phosphorylation. IkB- $\alpha$ is a physiological ligand of NF-kB in the cytoplasm, whose phosphorylation permits the liberation and migration of NF-kB into the nucleus, where NF-kB plays its transcriptional role, up-regulating the expression of cell cycle regulators, anti-apoptotic proteins, growth factors, negative regulators of the NF-kB pathway and immunoregolatory cytokines [89-94].

Initially immunohistochemical evaluation of Bcl10 has been proposed as a good surrogate marker of translocations in MALT lymphomas. In fact the nuclear expression of bcl10 could suggest NF-kB activation after $\mathrm{t}(11 ; 18)$ (q21; $\mathrm{q} 21), \mathrm{t}(1 ; 14)(\mathrm{p} 22 ; \mathrm{q} 32)$, while strong cytoplasmic perinuclear expression seems to be linked to $\mathrm{t}(14 ; 18)(\mathrm{q} 32 ; \mathrm{q} 21)$ $[28,89,95-97]$. It was later noticed that a certain percentage of OAML missing t $(11 ; 18)$ [26] or t $(1 ; 14)$ [29] and lymphoplasmacytoid lymphomas [98] which lack a specific Bcl10 translocation showed a moderate nuclear Bcl10 expression. Moreover in another study an association between weak cytoplasmic Bcl10 expression and translocation $(14 ; 18)$ has been found in only 3 cases [5].

Recently, FOXP1 (located at 3p14) was identified as a new translocation partner of IGH (q32) at low frequency in MALT lymphomas and in DLBCL $[99,100]$.

In another recent study of 29 extragastric MALT lymphomas, the cases of ocular adnexal MALT lymphoma showed the ODZ2-IGH $(5 ; 14)$, JMJD2C-IGH $(9 ; 14)$ new translocations and two translocations with unknown 

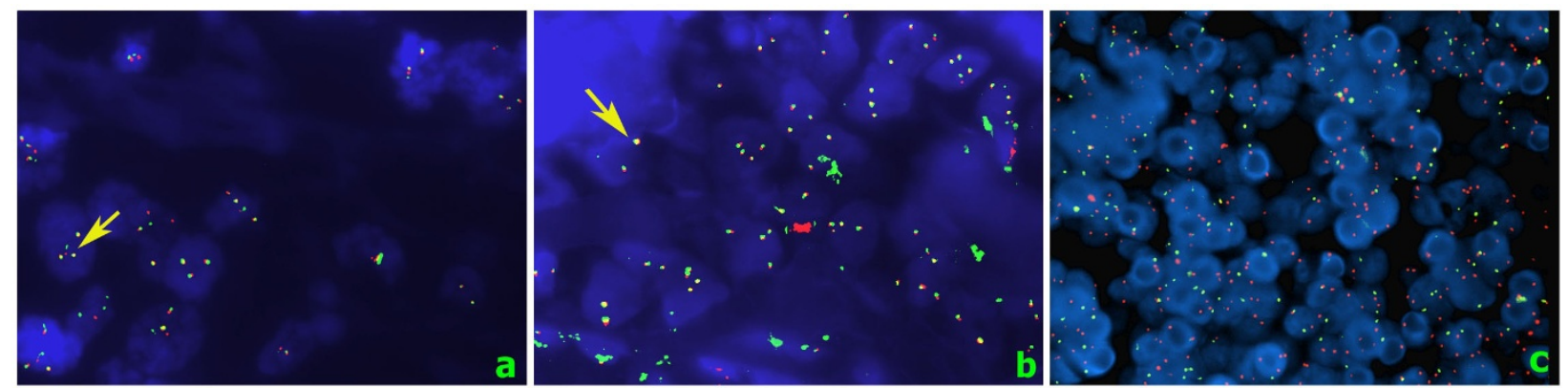

Figure 5 FISH; (a) T $(11 ; 18)(100 \times)$. Yellow fusion signals (arrow) of API2 (green) and MALT1 (red) translocation; (b) T (14;18) (100x). Yellow fusion signals (arrow) of IGH (green) and MALT1 (red); (c) T $(1 ; 14)$. (60x) Dual color break Apart rearrangement BCL10 probe. Following the translocation, there is a split signal.

partners of IGH $[101,102]$. In a case of conjunctival MALT lymphoma has been reported yet another new translocation, the $\mathrm{t}(5 ; 11)(\mathrm{q} 33 ; \mathrm{p} 11.2)$, not previously described [103].

Recently, another possible mechanism for uncontrolled NF-kB activation in MALT lymphoma, particularly in the ocular adnexa, salivary gland and thyroid MALT lymphoma, is generated by homozygous deletion of the chromosomal band $6 \mathrm{q} 23$ with subsequent loss of the tumor necrosis factor alpha-induced protein 3 (TNFAIP3, A20) [104], an essential global NF-kB inhibitor. A20 is also inactivated frequently by somatic mutations [105-107]. In OAML, A20 inactivation is associated with poor lymphoma-free survival $[104,105,108,109]$ and with a range of chronic inflammatory disorders [110-114].

\section{Treatment}

The treatment depends upon the variables related to the patient (age, autoimmune disorders) and to the disease, particularly on site, stage and surgical accessibility. Surgical excision is most appropriate for many stage 1 conjunctival and lachrymal gland MALT lymphomas, especially in pseudoencapsulated lesions [30]. 'Wait and watch' strategy after surgical resection in patients with stage I disease produces similar results to those reported with immediate radiotherapy, in terms of progression, systemic dissemination, transformation in an advanced stage disease and death associated with lymphoma, with a 10-year overall survival of 94\% [38]. The localized low grade OAML can be successfully managed with local radiotherapy. Ocular complications of radiotherapy, including cataract, retinal disorder, xerophthalmia and glaucoma, are frequently reported in patients that have long-term follow up [115]. There are few data in the literature regarding the use of chemotherapy in patients with OAML. Is it clear that is more effective administration of individual chemotherapeutic agents, as chlorambucil or fludarabine, for lowgrade lymphomas, and the combinations of chemotherapy, as cyclophosphamide, doxorubicin, prednisone and vincristine, for high grade lymphomas $[39,116]$. The largest experience regards chlorambucil, an alkylating agent largely used in indolent lymphomas. This drug is an active and well-tolerated therapy for stage I OAML, with a 67$100 \%$ response rate, a $79 \%$ complete remission rate, recurrence in up to $29 \%$ and a 5 -year relapse-free survival of $60 \%[30,97,112]$. Immunotherapy includes interferon $\alpha$ and rituximab (anti-CD20 antibody). Rituximab is a monoclonal antibody against $\mathrm{CD} 20$ positive $\mathrm{B}$ cells, which is being considered as an alternative first line treatment for localized CD20 positive OAML to avoid the ocular complications of radiotherapy [117-120]. As for the gastric MALT lymphoma, antibiotic therapy, aimed to eradicate the Hp infection, is followed by lymphoma regression in $60-70 \%$ of stage IE cases [121]. Thus also for OAML associated with $\mathrm{Cp}$ infection an antibiotic therapy has been proposed. Results following first line antibiotic treatment are variable [122]. Ferreri et al. documented an encouraging response following oral doxycycline for 3 weeks in 4 out of 9 patients with Cp positive OAML [12]. Abramson et al. showed a clinical response following antibiotic treatment in 3 patients with OAML [123], but Grunberger et al. did not obtain the same results. In another study 27 patients with OAML were treated with oral doxycycline [124]. Cp infection positive cases had an overall response rate of $64 \%$, and also the Cp DNA negative cases showed a clinical response with a rate of $36 \%$, indicating that doxycycline could be used in most OAML patients, independently of the diagnosis of Cp infection $[30,64,117]$. In a retrospective analysis of 38 patients with localized OAML, Kim et al. evaluated the effect of doxycycline for 3 weeks (12 patients) or 6 weeks (26 patients) [125]. After a median follow-up of 26.4 months, doxycycline resulted in an overall response rate of $47 \%$. Patients treated with doxycycline for 6 weeks versus 3 weeks tended to have a higher response rate ( $54 \%$ vs $33 \%)$.

Doxycycline may be also a valid therapeutic alternative in disseminated OAML [126]. 6 patients with disseminated $\mathrm{Cp}$-positive OAML were treated with doxycycline. 
After treatment, Cp DNA was not detectable in peripheral blood mononuclear cells of the six patients, and after a median follow-up of 31 months, three patients achieved an objective response [126].

\section{Conclusions}

The diagnosis and therapy of OAML requires a strict multidisciplinary approach. In this context the presence of $\mathrm{Cp}$ and the occurrence of specific chromosomal aberrations could add important information in order to better personalize the therapy. However further insights are needed about $\mathrm{Cp}$ induced lymphomagenesis, in particular with regard to specific antigens related to lymphoma occurrence and the role of the host immunity in lymphoma progression. Finally the absence of $\mathrm{Cp}$ in most patients with OAML, even in front of a therapeutic response to antibiotic-therapy, induces on the one hand to improve the diagnostic tool of $\mathrm{Cp}$ infection on biological samples from OAML patients and on the other to seek further infectious agents potentially responsible of tumor initiation.

\section{Author details}

'Pathology Unit, National Cancer Institute "Giovanni Pascale", Naples, Italy. ${ }^{2}$ Hematology Institute, "Federico II" University, Naples, Italy.

${ }^{3}$ Biomorphological and Functional Sciences Department, "Federico II" University, Naples, Italy. ${ }^{4}$ Pathology Unit, National Cancer Institute "Giovanni Pascale", Via Mariano Semmola, 80131 Naples, Italy.

\section{Authors' contributions}

$R F$ and FC have dealt with the drafting of the manuscript. ADC, GB, GDR, $A D R$ and RF have made a critical revision of the manuscript by introducing important intellectual content. All authors read and approved the final approval version of the manuscript.

\section{Competing interests}

All authors of this manuscript report no competing interests with respect to any financial or personal relationships with other people or organizations that could inappropriately influence our work.

Received: 11 January 2012 Accepted: 2 April 2012

Published: 2 April 2012

\section{References}

1. Margo CE, Mulla ZD: Malignant tumors of the orbit. Analysis of the Florida cancer registry. Ophthalmology 1998, 105(1):185-190.

2. Sasai K, Yamabe H, Dodo Y, Kashii S, Nagata Y, Hiraoka M: Non-Hodgkin's lymphoma of the ocular adnexa. Acta Oncol 2001, 40(4):485-490.

3. Mannami T, Yoshino T, Oshima K, Takase S, Kondo E, Ohara N, Nakagawa H, Ohtsuki H, Harada M, Akagi T: Clinical, histopathological, and immunogenetic analysis of ocular adnexal lymphoproliferative disorders: characterization of malt lymphomaMod. Pathol 2001, 14(7):641-649.

4. Moslehi R, Devesa SS, Schairer C, Fraumeni JF Jr: Rapidly increasing incidence of ocular non-Hodgkin lymphoma. J Natl Cancer Inst 2006, 98(13):936-939.

5. Franco R, Camacho Fl, Caleo A, Staibano S, Bifano D, De Renzo A, Tranfa F De Chiara A, Botti G, Merola R, Diez A, Bonavolontà G, De Rosa G, Piris MA: Nuclear bcl10 expression characterizes a group of ocular adnexa MALT lymphomas with shorter failure-free survival. Mod Pathol 2006, 19:1055-1067.

6. DU MQ: MALT lymphoma: recent advances in aetiology and molecular genetics. J Clin Exp Hematophatol 2007, 47(2):31-42.
7. Doglioni C, Wotherspoon A, Moschini A, De Boni M, Isaacson PG: High incidence of primary gastric lymphoma in northeastern Italy. Lancet 1992, 339:834-835.

8. Parsonnet J, Hansen $S$, Rodriguez $L$, Gelb AB, Warnke RA, Jellum E Orentreich N, Vogelman JH, Friedman GD: Helicobacter pylori infection and gastric lymphoma. N Engl J Med 1994, 330:1267-1271.

9. Lecuit M, Abachin E, Martin A, Poyart C, Pochart P, Suarez F, Bengoufa D, Feuillard J, Lavergne A, Gordon JI, Berche P, Guillevin L, Lortholary O: Immunoproliferative small intestinal disease associated with Campylobacter jejuni. N Engl J Med 2004, 350:239-248.

10. Jelic S, Filipovic-Ljeskovic I: Positive serology for Lyme disease borrelias in primary cutaneous B-cell lymphoma: a study in 22 patients; is it a fortuitous finding? Hematol Oncol 1999, 17:107-116.

11. Ferreri AJ, Guidoboni M, Ponzoni M, De Conciliis C, Dell'Oro S, Fleischhauer K, Caggiari L, Lettini AA, Dal Cin E, leri R, Freschi M, Villa E, Boiocchi M, Dolcetti R: Evidence for an association between chlamydia psittaci and ocular adnexal lymphoma. J Natl Cancer Inst 2004, 96:586-594.

12. Ferreri AJ, Ponzoni M, Guidoboni M, De Conciliis C, Resti AG, Mazzi B, Lettini AA, Demeter J, Dell'Oro S, Doglioni C, Villa E, Boiocchi M, Dolcetti R: Regression of ocular adnexal lymphoma after Chlamydia psittacieradicating antibiotic therapy. J Clin Oncol 2005, 23:5067-5073.

13. Yoo C, Ryu MH, Huh J, Park JH, Kang HJ, Ahn HS, Lee Y, Kim MJ, Lee H, Kim TW, Chang HM, Lee JL, Kang YK: Chlamydia psittaci infection and clinicopathologic analysis of ocular adnexal lymphomas in Korea. Am J Hematol 2007, 82:821-823.

14. Aigelsreiter A, Leitner E, Deutsh A, Kessler HH, Stelzl E, Beham-Schmid C, Beham A, Krugmann J, Dinges HP, Linkesch W, Neumeister P: Chlamydia psittaci in MALT lymphomas of ocular adnexals: the Austrian experience. Leuk Res 2008, 32:1292-1294.

15. Chanudet E, Zhou Y, Bacon CM, Wotherspoon AC, Müller-Hermelink HK, Adam P, Dong HY, de Jong D, Li Y, Wei R, Gong X, Wu Q, Ranaldi R, Goteri G, Pileri SA, Ye H, Hamoudi RA, Liu H, Radford J, Du MQ: Chlamydia psittaci is variably associated with ocular adnexal MALT lymphoma in different geographical regions. J Pathol 2006, 209(3):344-351.

16. Gracia E, Froesch P, Mazzucchelli L, Martin V, Rodríguez-Abreu D, Jiménez J, Melgares M, Santos D, Capó V, Cavalli F, Zucca E, Bertoni F: Low prevalence of Chlamydia psittaci in ocular adnexal lymphomas from Cuban patients. Leuk Lymphoma 2007, 48(1):104-108

17. Carugi A, Onnis A, Antonicelli G, Rossi B, Mannucci S, Luzzi A, Lazzi S, Bellan C, Tosi GM, Sayed S, De Falco G, Leoncini L: Geographic variation and environmental conditions as cofactors in Chlamydia psittaci association with ocular adnexal lymphomas: a comparison between Italian and African samples. Hematol Oncol 2010, 28(1):20-26.

18. Vargas RL, Fallone E, Felgar RE, Friedberg JW, Arbini AA, Andersen AA, Rothberg PG: Is there an association between ocular adnexal lymphoma and infection with Chlamydia psittaci? The University of Rochester experience. Leukemia Res 2006, 30:547-551.

19. Rosado MF, Byrne GE Jr, Ding F, Fields KA, Ruiz P, Dubovy SR, Walker GR, Markoe A, Lossos IS: Ocular adnexal lymphoma: a clinicopathologic study of a large cohort of patients with no evidence for an association with Chlamydia psittaci. Blood 2006, 107:467-472.

20. Zang D, Dong L, Li H, Jin H, Ye H, Zhou X, Gao Z, Dong G, Zhu J, Liu H, Gong L: Ocular adnexal mucosa-associated lymphoid tissue lymphoma in Northern China: high Frequency of numerical chromosomal changes and no evidence of an association with Chlamydia psittaci. Leuk Lymphoma 2010, 51(11):2031-2038.

21. Matthews JM, Moreno LI, Dennis J, Byrne GE Jr, Ruiz P, Dubovy SR, Lossos IS: Ocular adnexal lymphoma: no evidence for bacterial DNA associated with lymphoma pathogenesis. Br J Haematol 2008, 142:246-249

22. Yakushijin Y, Kodama T, Takaoka I, Tanimoto K, Bessho H, Sakai I, Hato T, Hasegawa H, Yasukawa M: Absence of Chlamydial infection in Japanese patients with ocular adnexal lymphoma of mucosa-associated lymphoid tissue. Int J Hematol 2007, 85:223-230.

23. Liu YC, Ohyashiki JH, Ito Y, Iwaya K, Serizawa H, Mukai K, Goto H, Usui M, Ohyashiki K: Chlamydia psittaci in ocular adnexal lymphoma: Japanese experience. Leuk Res 2006, 30(12):1587-1589.

24. Mulder MM, Heddema ER, Pannekoek Y, Faridpooya K, Oud ME, SchilderTol E, Saeed P. Pals ST: No evidence for an association of ocular adnexal 
lymphoma with Chlamydia psittaci in a cohort of patients from the Netherlands. Leuk Res 2006, 10:1305-1307.

25. De Cremoux P, Subtil A, Ferreri AJ, Vincent-Salomon A, Ponzoni M, Chaoui D, Arnaud P, Lumbroso-Le Rouic L, Sacchetti F, Dendale R, Thioux M, Escande MC, Stern MH, Dolcetti R, Decaudin D: Low prevalence of Chlamydia psittaci infection in french patients with ocular adnexal Iymphomas. J Natl Cancer Inst 2006, 98:365-366.

26. Ye H, Liu H, Attygalle A, Wotherspoon AC, Nicholson AG, Charlotte F, Leblond V, Speight P, Goodlad J, Lavergne-Slove A, Martin-Subero Jl, Siebert R, Dogan A, Isaacson PG, Du MQ: Variable frequencies of $t(11 ; 18)$ (q21;q21) in MALT lymphomas of different lymphoma sites: significant association with CagA strains of $H$ pylori in gastric MALT. Blood 2003, 101:2335-2339

27. Streubel B, Simonitsch-Klupp I, Muellauer L, Lamprecht A, Huber D, Siebert R, Stolte M, Trautinger F, Lukas J, Püspök A, Formanek M, Assanasen T, Müller-Hermelink HK, Cerroni L, Raderer M, Chott A: Variable frequencies of MALT lymphoma-associated genetic aberrations in MALT lymphomas of different sites. Leukemia 2004, 18:1722-1726.

28. Streubel B, Lamprecht A, Dierlamm J, Cerroni L, Stolte M, Ott G, Raderer M, Chott $A: T(14 ; 18)(q 32 ; q 21)$ involving IGH and MALT1 is a frequent chromosomal aberration in MALT lymphoma. Blood 2003, 101:2335-2339.

29. Adachi A, Tamaru J-I, Kaneko K, Kuroda H, Miura I, Kojima T, Hoshino S, Ichinohasama R, Itoyama S: No evidence of correlation between BCL10 expression and API2- MALT1 gene rearrangement in ocular adnexal MALT Iymphoma. Path Intern 2004, 54:16-25.

30. Ferreri AJ, Dolcetti R, Due M-Q, Ponzoni Kuroda H, Miura I, Kojima T, Hoshino S, Ichinohasama R, Itoyama S: Ocular adnexal MALT lymphoma: an intriguing model for antigen-driven lymphomagenesis and microbialtargeted therapy. Ann Oncol 2007, 19(5):835-846.

31. Bhatia S, Paulino AC, Buatti JM, Mayr NA, Wen BC: Curative radiotherapy for primary orbital lymphoma. Int I Radiat Oncol Biol Phys 2002. 54(3):818-823.

32. Martinet $S$, Ozsahin M, Belkacemi Y, Landmann C, Poortmans P, Oehlere C Scandolaro L, Krengli M, Maingon P, Miralbell R, Studer G, Chauvet B, Marnitz S, Zouhair A, Mirimanoff RO: Outcome and prognostic factors in orbital lymphoma: a rare cancer network study on 90 consecutive patients treated with radiotherapy. Int J Radiat Oncol Biol Phys 2003, 55(4):892-898.

33. Uno T, Isobe K, Shikama N, Nishikawa A, Oguchi M, Ueno N, Itami J, Ohnishi H, Mikata A, Ito H: Radiotherapy for extranodal, marginal zone, Bcell lymphoma of mucosa-associated lymphoid tissue originating in the ocular adnexa: a multiinstitutional, retrospective review of 50 patients. Cancer 2003, 98(4):865-871.

34. Fung CY, Tarbell NJ, Lucarelli MJ, Goldberg SI, Linggood RM, Harris NL, Ferry JA: Ocular adnexal lymphoma: clinical behavior of distinct world health organization classification subtypes. Int I Radiat Oncol Biol Phys 2003, 57(5):1382-1391.

35. Raderer M, Wohrer S, Streubel B, Troch M, Turetschek K, Jäger U, Skrabs C, Gaiger A, Drach J, Puespoek A, Formanek M, Hoffmann M, Hauff W, Chott A: Assessment of disease dissemination in gastric compared with extragastric mucosa-associated lymphoid tissue lymphoma using extensive staging: a single-center experience. J Clin Oncol 2006, 24(19):3136-3141.

36. Raderer M, Osterreicher C, Machold K, Formanek M, Fiebiger W, Penz M Dragosics B, Chott A: Impaired response of gastric MALT Iymphoma to helicobacter pylori eradication in patients with autoimmune disease. Ann Oncol 2001, 12(7):937-939.

37. Sarraf D, Jain A, Dubovy S, Kreiger A, Fong D, Paschal J: Mucosa-associated lymphoid tissue lymphoma with intraocular involvement. Retina 2005, 25(1):94-98.

38. Tanimoto K, Kaneko A, Suzuki S, Sekiguchi N, Maruyama D, Kim SW, Watanabe T, Kobayashi Y, Kagami Y, Maeshima A, Matsuno Y, Tobinai K: Long-term follow-up results of no initial therapy for ocular adnexal MALT Iymphoma. Ann Oncol 2006, 17(1):135-140.

39. Ben Simon GJ, Cheung N, McKelvie P, Fox R, McNab AA: Oral chlorambucil for extranodal, marginal zone, B-cell lymphoma of mucosa-associated lymphoid tissue of the orbit. Ophthalmology 2006, 113(7):1209-1213.

40. Matsuo T, Yoshino T: Long-term follow-up results of observation or radiation for conjunctival malignant lymphoma. Ophthalmology 2004, 111(6):1233-1237.
41. Du MQ, Isaccson PG: Gastric MALT lymphoma: from aetiology to treatment. Lancet Oncol 2002, 3(2):97-104.

42. Neri A, Jakobiec FA, Pelicci PG, Dalla-Favera R, Knowles DM: Immunoglobulin and T cell receptor beta chain gene rearrangement analysis of ocular adnexal lymphoid neoplasms: clinical and biologic implications. Blood 1987, 70(5):1519-1529.

43. Goodlad JR, Davidson MM, Hollowood K, Batstone P, Ho-Yen DO: Borrelia burgdorferi-associated cutaneous marginal zone lymphoma: a clinicopathological study of two cases illustrating the temporal progression of B. burgdorferi-associated B-cell proliferation in the skin. Histopathology 2000, 37:501-508.

44. Cerroni L, Zochling N, Putz B, Kerl K: Infection by Borrelia burgdorferi and cutaneous B-cell lymphoma. J Cutan Pathol 1997, 24:457-461.

45. Garbe C: Borrelia infections of the skin-progress of knowledge since the discovery of Lyme disease. Hautarzt 1991, 42:356-365.

46. Neumeister P, Hoefler G, Beham-Schmid C, Schmidt H, Apfelbeck U, Schaider H, Linkesch W, Sill H: Deletion analysis of the p16 tumor suppressor gene in gastrointestinal mucosa-associated lymphoid tissue lymphomas. Gastroenterology 1997, 112(6):1871-1875.

47. Kaune KM, Neumann C, Hallermann C, Haller F, Schön MP, Middel P: Simultaneous aberrations of single CDKN2A network components and a high $\mathrm{Rb}$ phosphorylation status can differentiate subgroups of primary cutaneous B-cell lymphomas. Exp Dermatol 2011, 20(4):331-335.

48. Camacho Fl, Mollejo M, Mateo MS, Algara P, Navas C, Hernández JM, Santoja C, Solé F, Sánchez-Beato M, Piris MA: Progression to large B-cell lymphoma in splenic marginal zone lymphoma: a description of a series of 12 cases. Am J Surg Pathol 2001, 25(10):1268-1276.

49. Dierlamm J, Stefanova M, Wlodarska I, Hinz K, Maes B, Michaux L, Stul M, Verhoef G, Thomas J, De Wolf-Peeters C, Van den Berghe H, Hossfeld DK, Hagemeijer A: Analysis of the P53, RB/D13S25, and P16 tumor suppressor genes in marginal zone B-cell lymphoma: an interphase fluorescence in situ hybridization study. Cancer Genet Cytogenet 2000, 120(1):1-5

50. Ponzoni M, Ferreri AJ, Guidoboni M, Lettini AA, Cangi MG, Pasini E, Sacchi L, Pecciarini L, Grassi S, Dal Cin E, Stefano R, Magnino S, Dolcetti R, Doglioni C: Chlamydia infection and lymphomas: association beyond ocular adnexal lymphomas highlighted by multiple detection methods. Clin Cancer Res $2008,14: 5794-5800$

51. Zhang DD, Liu HG, Li HY, Gao ZF, Zhou XG, Jin HS, Dong LN, Zhang J, Gong LP: Relationship between primary ocular adnexal mucosaassociated lymphoid tissue lymphoma and eye infection. Zhonghua Bing Li Xue Za Zhi 2009, 38(8):513-518.

52. Abrams JT, Balin BJ, Vonderheid EC: Association between Sazary T-cellactivating factor, Chlamydia pneumonia, and cutaneus T cell lymphoma. Ann N Y Acad Sci 2001, 941:69-85.

53. Chan CC, Shen D, Mochizuki M, Gonzales JA, Yuen HK, Guex-Crosier Y, Lehoang P: Detection of Helicobacter pylori and Chlamydia pneumonia genes in primary orbital Lymphoma. Trans Am Ophthalmol Soc 2006, 104:62-70.

54. Littman AJ, Jackson LA, Vaughan TI: Chlamydia pneumonia and lung cancer: epidemiologic evidence. Cancer Epidemiol Biomarkers Prev 2005 14:773-778.

55. Shen D, Yuen HK, Galita DA, Chan NR, Chan CC: Detection of Chlamydia pneumoniae in a Bilateral Orbital Mucosa-Associated Lymphoid Tissue Lymphoma. Am J Ophthalmol 2006, 141(6):1162-1163.

56. Ferreri AJ, Ponzoni M, Viale E, Guidoboni M, Conciliis CD, Resti AG, Politi L, Lettini AA, Sacchetti F, Dognini G, Dolcetti R, Doglioni C: Association between Helicobacter pylori infection and MALT-type lymphoma of ocular adnexa: clinical and therapeutic implications. Hematol Oncol 2006, 24:33-37.

57. Lee SB, Yang JW, Kim CS: The association between conjunctival MALT lymphoma and Helicobacter pylori. Br J Ophtalmol 2008, 92:534-536.

58. Goebel N, Serr A, Mittelviefhaus H, Reinhard T, Bogdan C, Auw-Haedrich C: Chlamydia psittaci, Helicobacter pylori and ocular adnexal lymphoma-is there an association? The German experience. Leuk Res 2007, 31:1450-1452

59. Sjo NC, Foegh $P$, Juhl BR, Nilsson HO, Prause JU, Ralfkiaer E, Wadström $T$, Heegaard S: Role of Helicobacter pylori in conjunctival mucosaassociated lymphoid tissue lymphoma. Ophtalmology 2007, 114:182-186

60. Stefanovic A, Lossos IS: Extranodal marginal zone lymphoma of the ocular adnexa. Blood 2009, 114(3):501-510. 
61. Ferreri AJ, Viale $E$, Guidoboni $M$, Resti $A G$, De Conciliis $C$, Politi L, Lettini AA, Sacchetti F, Dolcetti R, Doglioni C, Ponzoni M: Clinical implications of hepatitis $C$ virus infection in MALTtype lymphoma of the ocular adnexa. Ann Oncol 2006, 17:769-772.

62. Arcaini L, Burcheri $S$, Rossi A, Paulli M, Bruno R, Passamonti F, Brusamolino E, Molteni A, Pulsoni A, Cox MC, Orsucci L, Fabbri A, Frezzato M, Voso MT, Zaja F, Montanari F, Merli M, Pascutto C, Morra E, Cortelazzo S, Lazzarino M: Prevalence of HCV infection in nongastric marginal zone B-cell lymphoma of MALT. Ann Oncol 2007, 18:346-350.

63. Harkinezhad T, Geens T, Vanrompay D: Chlamydophila psittaci infections in birds: A rewiew with emphasis on zoonotic consequences. Vet Microbiol 2009, 135(1-2):68-77.

64. Ferreri AJ, Ponzoni M, Guidoboni M, Resti AG, Politi LS, Cortelazzo S, Demeter J, Zallio F, Palmas A, Muti G, Dognini GP, Pasini E, Lettini AA, Sacchetti F, De Conciliis C, Doglioni C, Dolcetti R: Bacteria-eradicating therapy with doxycycline in ocular adnexal MALT lymphoma: a multicenter prospective trial. J Natl Cancer Inst 2006, 98:1375-1382.

65. Byrne Gl, Ojcius DM: Chlamydia and apoptosis: life and death decisions of an intracellular pathogen. Nat Rev Microbiol 2004, 2:802-808.

66. Lehtinen M, Rantala I, Aine R, Miettinen A, Laine S, Heinonen P, Teisala K, Punnonen R, Paavonen J: B cell response in Chlamydia trachomatis endometritis. Eur J Clin Microbiol 1986, 5:596-598.

67. Miyairi I, Byrne Gl: Chlamydia and programmed cell death. Curr Opin Microbiol 2006, 9:102-108

68. Ferreri AJ, Ernberg I, Copie-Bergman C: Infectious agents and lymphoma development: molecular and clinical aspects. J Intern Med 2009, 265:421-438.

69. Pockley AG: Heat shock proteins as regulators of the immune response. Lancet 2003, 362(9382):469-476.

70. Ishii E, Yokota K, Sugiyama T, Fujinaga Y, Ayada K, Hokari I, Hayashi S, Hirai Y, Asaka M, Oguma K: Immunoglobulin G1 antibody response to helicobacter pylori heat shock protein 60 is closely associated with lowgrade gastric mucosa-associated lymphoid tissue lymphoma. Clin Diagn Lab Immunol 2001, 8(6):1056-1059.

71. Suerbaum S, Michetti P: Helicobacter pylori infection. N Engl J Med 2002, 347:1175-1186

72. Cerutti PA, Trump BF: Inflammation and oxidative stress in carcinogenesis. Cancer Cells 1991, 3:1-7.

73. Owens SR, Smith LB: Molecular Aspects of H. pylori-Related MALT Lymphoma. Patholog Res Int 2011, 2011:193149.

74. Zullo A, Hassan C, Cristofari F, Perri F, Morini S: Gastric low-grade mucosalassociated lymphoid tissue-lymphoma: Helicobacter pylori and beyond. World J Gastrointest Oncol 2010, 2(4):181-186.

75. Jaffe ES: Common threads of mucosa-associated lymphoid tissue lymphoma pathogenesis: from infection to translocation. $J$ Natl Cancer Inst 2004, 96(8):571-573.

76. Ruiz A, Reischl U, Swerdlow SH, Hartke M, Streubel B, Procop G, Tubbs RR, Cook JR: Extranodal marginal zone lymphomas of the ocular adnexa. Multiparameter analysis of 34 cases including interphase molecular cytogenetics and PCR for Chlamydia psittaci. Am J Surg Pathol 2007, 31:792-802.

77. Gruenberger B, Woehrer S, Troch M, Hauff W, Lukas J, Streubel B, Muellauer L, Chott A, Raderer M: Assessment of the role of hepatitis C, Helicobacter phylori and autoimmunity in MALT lymphoma of the ocular adnexa in 45 Austrian patients. Acta Oncologica 2008, 47:355-359.

78. Tanimoto K, Sekiguchi N, Yokota Y, Kaneko A, Watanabe T, Maeshima AM, Matsuno $Y$, Harada M, Tobinai $K$, Kobayashi Y: Fluorescence in situ hybridization (FISH) analysis of primary ocular adnexal MALT lymphoma. BMC Cancer 2006, 6:249-258.

79. Matteucci C, Galieni P, Leoncini L, Lazzi S, Lauria F, Polito E, Martelli MF, Mecucci C: Typical genomic imbalance in primary MALT lymphoma of the orbit. J Pathol 2003, 200(5):656-660

80. Dierlamm J, Baens M, Wlodarska I, Stefanova-Ouzounova M, Hernandez JM, Hossfeld DK, De Wolf-Peeters C, Hagemeijer A, Van den Berghe $H$, Marynen P: The apoptosis inhibitor gene API2 and a novel $18 \mathrm{q}$ gene, $M L T$, are recurrently rearranged in the $t(11 ; 18)(q 21 ; q 21)$ associated with mucosa-associated lymphoid tissue lymphomas. Blood 1999, 93(11):3601-3609.

81. Akagi T, Motegi M, Tamura A, Suzuki R, Hosokawa Y, Suzuki H, Ota H, Nakamura S, Morishima Y, Taniwaki M, Seto M: A novel gene, MALT1 at $18 \mathrm{q} 21$, is involved in $\mathrm{t}(11 ; 18)(\mathrm{q} 21 ; \mathrm{q} 21)$ found in low-grade B-cell lymphoma of mucosa-associated lymphoid tissue. Oncogene 1999 18(42):5785-5794.

82. Morgan JA, Yin Y, Borowsky AD, Kuo F, Nourmand N, Koontz Jl, Reynolds C, Soreng L, Griffin CA, Graeme-Cook F, Harris NL, Weisenburger D, Pinkus GS, Fletcher JA, Sklar J: Breakpoints of the $t(11 ; 18)(q 21 ; q 21)$ in mucosaassociated lymphoid tissue (MALT) lymphoma lie within or near the previously undescribed gene MALT1 in chromosome 18. Cancer Res 1999, 59(24):6205-6213.

83. DU MQ: MALT lymphoma: many roads lead to nuclear factor-kb activation. Histopathology 2011, 58:26-38.

84. Lucas PC, Yonezumi M, Inohara N, McAllister-Lucas LM, Abazeed ME, Chen FF, Yamaoka S, Seto M, Nunez G: Bcl10 and MALT1, independent targets of chromosomal translocation in malt lymphoma, cooperate in a novel NF-kappa B signaling pathway. J Biol Chem 2001 276(22):19012-19019.

85. Uren AG, O'Rourke K, Aravind LA, Pisabarro MT, Seshagiri S, Koonin EV, Dixit VM: Identification of paracaspases and metacaspases: two ancient families of caspase-like proteins, one of which plays a key role in MALT lymphoma. Mol Cell 2000, 6(4):961-967.

86. Ruland J, Duncan GS, Elia A, Del Barco Barrantes I, Nguyen L, Plyte S, Millar DG, Bouchard D, Wakeham A, Ohashi PS, Mak TW: Bcl10 is a positive regulator of antigen receptor-induced activation of NF-kappaB and neural tube closure. Cell 2001, 104:33-42.

87. Xue L, Morris SW, Orihuela C, Tuomanen E, Cui X, Wen R, Wang D: Defective development and function of Bcl10-deficient follicular, marginal zone and B1 B cells. Nat Immunol 2003, 4:857-865

88. Thome M: CARMA1, BCL-10 and MALT1 in lymphocyte development and activation. Nat Rev Immunol 2004, 4:348-359.

89. Sanchez-Beato M, Sanchez-Aguilera A, Piris MA: Cell cycle deregulation in B-cell lymphomas. Blood 2003, 101:1220-1235

90. Liu Y, Dong W, Chen L, Zhang P, Qi Y: Characterization of bcl10 as a potential transcriptional activator that interacts with general transcription factor TFIIB. Biochem Biophys Res Commun 2004, 320:1-6.

91. Ghosh S, May MJ, Kopp EB: NF-kB and Rel proteins: evolutionarily conserved mediators of immune responses. Annu Rev Immunol 1998, 16:225-260.

92. Johnson C, Van Antwerp D, Hope TJ: An N-terminal nuclear export signal is required for the nucleocytoplasmic shuttling of IkBalpha. EMBO J 1999, 18:6682-6693.

93. Karin $\mathrm{M}$, Ben-Neriah $\mathrm{Y}$ : Phosphorylation meets ubiquitination: the control of NF-kB activity. Annu Rev Immunol 2000, 18:621-663.

94. Holzmann K, Kohlhammer H, Schwaenen C, Wessendorf S, Kestler HA, Schwoerer A, Rau B, Radlwimmer B, Döhner H, Lichter P, Gress T, Bentz M: Genomic DNA-chip hybridization reveals a higher incidence of genomic amplifications in pancreatic cancer than conventional comparative genomic hybridization and leads to the identification of novel candidate genes. Cancer Res 2004, 64:4428-4433.

95. Ye H, Gong L, Liu H, Hamoudi RA, Shirali S, Ho L, Chott A, Streubel B, Siebert R, Gesk S, Martin-Subero Jl, Radford JA, Banerjee S, Nicholson AG, Ranaldi R, Remstein ED, Gao Z, Zheng J, Isaacson PG, Dogan A, Du MQ: MALT lymphoma with $\mathrm{t}(14 ; 18)(\mathrm{q} 32 ; \mathrm{q} 21) / \mathrm{IGH}-\mathrm{MALT} 1$ is characterized by strong cytoplasmatic MALT1 and bcl10 expression. J Pathol 2005, 205:293-301.

96. Capello D, Gaidano G: Molecular pathophysiology of indolent lymphoma. Haematologica 2000, 85:195-201.

97. Kuo SH, Chen LT, Yeh KH, Wu MS, Hsu HC, Yeh PY, MAO TL, Chen CL, Doong SL, Lin JT, Cheng AL: Nuclear expression of bcl10 or nuclear factor kappa B predicts Helicobacter pylori-independent status of early-stage, highgrade gastric mucosa-associated lymphoid tissue lymphomas. J Clin Oncol 2004, 22:3491-3497.

98. Merzianu M, Jiang L, Lin P, Wang X, Weber DM, Vadhan-Raj S, Nguyen MH, Medeiros LJ, Bueso-Ramos CE: Nuclear BCL10 expression is common in lymphoplasmacytic lymphomas/Waldenstrom macroglobulinemia and does not correlate with p65 NF-kB activation. Mod Pathol 2006, 19:891-898.

99. Streubel B, Vinatzer U, Lamprecht A, Raderer M, Chott A: T(3;14) (p14.1; q32) involving IGH and FOXP1 is a novel recurrent chromosomal aberration in MALT lymphoma. Leukemia 2005, 19(4):652-658.

100. Haralambieva E, Adam P, Ventura R, Katzenberger T, Kalla J, Höller $S$ Hartmann M, Rosenwald A, Greiner A, Muller-Hermelink HK, Banham AH, Ott G: Genetic rearrangement of FOXP1 is predominantly detected in a 
subset of diffuse large B cell lymphomas with extranodal presentation. Leukemia 2006, 20(7):1300-1303.

101. Vinatzer U, Gollinger M, Mullauer L, Raderer M, Chott A, Streubel B: Mucosaassociated lymphoid tissue lymphoma: novel translocations involving ODZ2, JMJD2C and CNN3. Clin Canc Res 2008, 21:902-911.

102. McKelvie PA: Ocular Adnexal Lymphomas: a rewiew. Adv Anat Pathol 2010, 17:251-261.

103. Clement CG, Potluri VR, Gonzales J, Qian YW: Translocation $(5 ; 11)$ in a conjunctival MALT lymphoma. Int J Clin Exp Pathol 2011, 4(7):722-726.

104. Honma K, Tsuzuki S, Nakagawa M, Karnan S, Aizawa Y, Kim WS, Kim YD, Ko YH, Seto M: TNFAIP3 is the target gene of chromosome band 6q23.3q24.1 loss in ocular adnexal marginal zone B cell lymphoma. Genes Chromosomes Cancer 2008, 47(1):1-7.

105. Chanudet E, Huang Y, Ichimura K, Dong G, Hamoudi RA, Radford J, Wotherspoon AC, Isaacson PG, Ferry J, Du MQ: A20 is targeted by promoter methylation, deletion and inactivating mutation in MALT lymphoma. Leukemia 2010, 24(2):483-487.

106. Novak U, Rinaldi A, Kwee I, Nandula SV, Rancoita PM, Compagno M, Cerri M, Rossi D, Murty W, Zucca E, Gaidano G, Dalla-Favera R, Pasqualucci $L$, Bhagat $G$, Bertoni $F$ : The NF-\{kappa\}B negative regulator TNFAIP3 (A20) is inactivated by somatic mutations and genomic deletions in marginal zone lymphomas. Blood 2009, 113(20):4918-4921.

107. Kato M, Sanada M, Kato I, Sato Y, Takita J, Takeuchi K, Niwa A, Chen Y, Nakazaki K, Nomoto J, Asakura Y, Muto S, Tamura A, lio M, Akatsuka Y, Hayashi Y, Mori H, Igarashi T, Kurokawa M, Chiba S, Mori S, Ishikawa Y, Okamoto K, Tobinai K, Nakagama H, Nakahata T, Yoshino T, Kobayashi Y, Ogawa S: Frequent inactivation of A20 in B-cell lymphomas. Nature 2009, 459(7247):712-716

108. Chanudet E, Ye H, Ferry J, Bacon CM, Adam P, Müller-Hermelink HK, Radford J, Pileri SA, Ichimura K, Collins VP, Hamoudi RA, Nicholson AG Wotherspoon AC, Isaacson PG, Du MQ: A20 deletion is associated with copy number gain at the TNFA/B/C locus and occurs preferentially in translocation-negative MALT lymphoma of the ocular adnexa and salivary glands. J Pathol 2009, 217(3):420-430

109. Kim WS, Honma K, Karnan S, Tagawa H, Kim YD, Oh YL, Seto M, Ko YH: Genome-wide array-based comparative genomic hybridization of ocular marginal zone $B$ cell lymphoma: comparison with pulmonary and nodal marginal zone B cell lymphoma. Genes Chromosomes Cancer 2007, 46(8):776-783

110. Vereecke $L$, Beyaert $R$, van Loo G: The ubiquitin-editing enzyme $A 20$ (TNFAIP3) is a central regulator of immunopathology. Trends Immunol 2009, 30(8):383-391.

111. Graham RR, Cotsapas C, Davies L, Hackett R, Lessard CJ, Leon JM, Burtt NP, Guiducci C, Parkin M, Gates C, Plenge RM, Behrens TW, Wither JE, Rioux JD, Fortin PR, Graham DC, Wong AK, Vyse TJ, Daly MJ, Altshuler D, Moser KL, Gaffney PM: Genetic variants near TNFAIP3 on $6 \mathrm{q} 23$ are associated with systemic lupus erythematosus. Nat Genet 2008, 40(9):1059-1061.

112. Dieguez-Gonzalez R, Calaza M, Perez-Pampin E, Balsa A, Blanco FJ, Cañete JD, Caliz R, Carreño L, de la Serna AR, Fernandez-Gutierrez B, Ortiz AM, Herrero-Beaumont G, Pablos JL, Narvaez J, Navarro F, Marenco JL, Gomez-Reino JJ, Gonzalez A: Analysis of TNFAIP3, a feedback inhibitor of nuclear factor-kappaB and the neighbor intergenic $6 \mathrm{q} 23$ region in rheumatoid arthritis susceptibility. Arthritis Res Ther 2009, 11(2):R42.

113. Plenge RM, Cotsapas C, Davies L, Price AL, de Bakker PI, Maller J, Pe'er I, Burtt NP, Blumenstiel B, DeFelice M, Parkin M, Barry R, Winslow W, Healy C, Graham RR, Neale BM, Izmailova E, Roubenoff R, Parker AN, Glass R, Karlson EW, Maher N, Hafler DA, Lee DM, Seldin MF, Remmers EF, Lee AT, Padyukov L, Alfredsson L, Coblyn J, et al: Two independent alleles at 6q23 associated with risk of rheumatoid arthritis. Nat Genet 2007. 39(12):1477-1482.

114. Musone SL, Taylor KE, Lu T, Nititham J, Ferreira RC, Ortmann W, Shifrin N, Petri MA, Kamboh MI, Manzi S, Seldin MF, Gregersen PK, Behrens TW, Ma A, Kwok PY, Criswell LA: Multiple polymorphisms in the TNFAIP3 region are independently associated with systemic lupus erythematosus. Nat Genet 2008, 40(9):1062-1064

115. Liao SL, Kao SC, Hou PK, Chen MS: Results of radiotherapy for orbital and adnexal lymphoma. Orbit 2002, 21:117-123.

116. Song EK, Kim SY, Kim TM, Lee KW, Yun T, Na II, Shin H, Lee SH, Kim DW, Khwarg SI, Heo DS: Efficacy of chemotherapy as first-line treatment in ocular adnexal extranodal marginal zone B cell lymphoma. Ann Oncol 2008, 19:242-246.
117. Cohen VM: Treatment options in ocular adnexa lymphoma (OAL). Clin Ophthalmol 2009, 3:689-692.

118. Conconi A, Martinelli G, Thieblemont C, Ferreri AJ, Devizzi L, Peccatori F, Ponzoni M, Pedrinis E, Dell'Oro S, Pruneri G, Filipazzi V, Dietrich PY, Gianni AM, Coiffier B, Cavalli F, Zucca E: Clinical activity of rituximab in extranodal marginal zone B-cell lymphoma of MALT type. Blood 2003, 102(8):2741-2745.

119. Nuckel H, Meller D, Steuhl KP, Dührsen U: Anti-CD20 monoclonal antibody therapy in relapsed MALT lymphoma of the conjunctiva. Eur I Haematol 2004, 73(4):258-262.

120. Ferreri AJ, Ponzoni M, Martinelli G, Muti G, Guidoboni M, Dolcetti R, Doglioni C: Rituximab in patients with mucosalassociated lymphoid tissue-type lymphoma of the ocular adnexa. Haematologica 2005, 90(11):1578-1579.

121. Isaacson PG, DU MQ: MALT lymphoma: from morphology to molecules. Nat Rev Cancer 2004, 4(8):644-653.

122. Husain A, Roberts D, Pro B, McLaughlin P, Esmaeli B: Meta-analyses of the association between Chlamydia psittaci and ocular adnexal lymphoma and the response of ocular adnexal lymphoma to antibiotics. Cancer 2007, 110:809-815

123. Abramson DH, Rollins I, Coleman M: Periocular mucosa-associated lymphoid/low grade lymphomas: treatment with antibiotics. Am J Ophthalmol 2005, 140:729-730.

124. Grunberger B, Hauff W, Lukas J, Wöhrer S, Zielinski CC, Streubel B, Chott A, Raderer M: 'Blind' antibiotic treatment targeting Chlamydia is not effective in patients with MALT lymphoma of the ocular adnexa. Ann Oncol 2006, 17:484-487.

125. Kim TM, Kim KH, Lee MJ, Jeon YK, Lee SH, Kim DW, Kim CW, Kim IH, Khwarg SI, Heo DS: First-line therapy with doxycycline in ocular adnexal mucosa-associated lymphoid tissue lymphoma: a retrospective analysis of clinical predictors. Cancer Sci 2010, 101(5):1199-1203.

126. Ferreri AJ, Dognini GP, Ponzoni M, Pecciarini L, Cangi MG, Santambrogio G, Resti AG, De Conciliiis C, Magnino S, Pasini E, Vicari N, Dolcetti R, Doglioni C: Chlamydia-psittaci-eradicating antibiotic therapy in patients with advanced-stage ocular adnexal MALT lymphoma. Ann Oncol 2008 19(1):194-195.

doi:10.1186/1750-9378-7-8

Cite this article as: Collina et al:: Chlamydia psittaci in ocular adnexa MALT lymphoma: a possible role in lymphomagenesis and a different geographical distribution. Infectious Agents and Cancer 2012 7:8.

\section{Submit your next manuscript to BioMed Central and take full advantage of:}

- Convenient online submission

- Thorough peer review

- No space constraints or color figure charges

- Immediate publication on acceptance

- Inclusion in PubMed, CAS, Scopus and Google Scholar

- Research which is freely available for redistribution 